\title{
Wirtualna scena - wirtualna publiczność. Wykorzystanie potencjału social media do promocji teatru
}

Streszczenie. Wykorzystywanie nowych mediów w dziedzinie teatru pozwala uruchomić całą gamę możliwości bezpośredniej komunikacji, w której zagwarantowana zostaje wyjątkowego rodzaju przestrzeń zarówno dla kolektywnego, jak i dla indywidualnego odbiorcy. Teatr korzystający z narzędzi cyfrowych na nowo otwiera się na widzów - także tych będących do tej pory, choćby z przyczyn ekonomicznych czy społecznych, często poza jego zasięgiem. Próba zachęcenia widza do interaktywnego uczestnictwa w konkretnym projekcie, wręcz uczestnictwa w grze, staje się elementem marketingu. Co ciekawe, marketing interaktywny coraz częściej staje się przyczynkiem do działań stricte artystycznych. Przykładem mogą tu być choćby przedsięwzięcia teatralne „Facebook live performance”. Tego typu projekty stają się częścią teatralnego repertuaru i elementem promocji.

Słowa kluczowe: teatr, intermedialność, marketing interaktywny

Dodejmowanie problemu wykorzystywania narzędzi social media w promocji sztuki i kreowaniu wizerunku instytucji kultury coraz częściej wiąże się z koniecznością konfrontacji czynników ekonomicznych z refleksją estetyczną. Obserwując niektóre projekty inicjowane przez instytucje kultury, można dojść do przekonania, że jako intermedialne i interaktywne przedsięwzięcia z pogranicza działań marketingowych i artystycznych stają się nie tylko elementem promocji, ale i częścią programu repertuarowego, a w końcu - kolejną płaszczyzną naukowego dyskursu. Szczególny jest tu oczywiście przypadek teatru, dla którego tak zwana kultura uczestnictwa dziś siła napędowa globalnego społeczeństwa informacyjnego - jest cechą dystynktywną. 
Teatr od zawsze bazował na indywidualnym przeżyciu widza i kolektywnym przeżyciu publiczności, budując szczególnego rodzaju model komunikacji - komunikacji opartej na osobistym doświadczeniu widza, powstałym w kontakcie z aktorem. Można więc powiedzieć, że potencjał indywidualnego kontaktu z odbiorcą i fenomen interaktywności, który na płaszczyźnie działań marketingowych właściwie doceniono dopiero wraz z końcem ery anonimowości i biernego odbioru treści zamieszczonych w Internecie, nie jest dla teatru żadnym novum.

Zasadniczym pytaniem, jakie nasuwa się dziś, gdy mówimy o udziale Internetu, w tym platform społecznościowych, w kształtowaniu wizerunku teatru jako instytucji społecznej - stawiającej pytania istotne z punktu widzenia tegoż społeczeństwa - miejsca wypowiedzi artystycznej, w końcu także instytucji oferującej szczególnego rodzaju usługi, jest pytanie o sposób zaadaptowania narzędzi social media dla szerokiego spektrum działań marketingowych i artystycznych. Nie można ponadto pominąć pytania o przeformułowanie, jakiemu ulega pojęcie komunikacji teatralnej. Ryzykowne byłoby sprzeczanie się z poglądem, że „media społecznościowe to nie moda, to fundamentalna zmiana w sposobie komunikacji" - jak zauważa Arkadiusz Podlaski [2011: 14]. Ta fundamentalna zmiana odbywa się także na płaszczyźnie teatralnego dyskursu. Mówienie dziś o podwójności komunikacji teatralnej musi być obłożone szeregiem przypisów zdeterminowanych przez zmianę narzędzi komunikowania. Przyglądając się temu, jak teatr anektujący nowe media sam dyskutuje z obligatoryjnymi dla swojego istnienia tworzywami, czyli przestrzenią, czasem i aktorem, należałoby poddać model komunikacji teatru pewnej redefinicji. Owszem, „teatr nie istnieje nigdy bez operacji na wszystkich tych tworzywach jednocześnie" [Świontek 2003: 41], ale wiele ze współczesnych projektów teatralnych dowodzi, że zasada dziania się teatru "tu i teraz" w obecności aktora i widza ulega niekiedy zawieszeniu, w tym sensie, że inne znaczenie zyskuje narratyw przestrzenny, a w konsekwencji zmienia się również status aktora i widza. Kiedy Erika Fischer-Lichte [2008: 96] zaznacza, że „współobecność aktorów i widzów w tej samej przestrzeni wywołuje i sankcjonuje wrażenie powstania wspólnoty", ma na myśli fizyczną współobecność - nie tyle bezpośredni kontakt fizyczny, ale właśnie współobecność, która może realizować się choćby przez akt wspólnego patrzenia na siebie. Nasuwa się zatem pytanie, czy o wspólnotowości (w kontekście zdarzenia teatralnego) możemy mówić także wtedy, gdy uczestnicy tegoż zdarzenia, owszem, patrzą w tym samym czasie, ale nie na siebie, albo mówiąc jeszcze inaczej, widzą 
nie siebie, ale swoje awatary lub sami stają się widzami i aktorami jednocześnie, i to w przestrzeni wirtualnej.

Pod koniec lat dziewięćdziesiątych XX w. Hans-Thies Lehmann, snując domysły o ewentualnym rozwoju i udziale mediów w teatrze, zastanawiał się, czy interakcje „oddalonych od siebie partnerów przy wykorzystaniu technologicznych udogodnień [...] trwale zajmą miejsce żywej sztuki teatru, której zasadą jest partycypacja?" [Lehmann 2004: 286]. Według Lehmanna zmiana zasadniczego modelu komunikacji w teatrze, czego, jego zdaniem, jesteśmy świadkami od co najmniej czterech dekad, wynika właśnie ze zmiany relacji między przestrzenią sceny i widowni, a mówiąc dokładniej, relacji między aktorem i widzem. Ten dychotomiczny związek zostaje zawieszony, przez co widz sytuuje się raczej w roli współtwórcy i wykonawcy performansu niż jego biernego obserwatora. Teatr, który Lehmann określa jako postdramatyczny, jest więc czymś więcej niż jedynie artefaktem istniejącym na zasadzie klasycznego podziału na scenę i widownię. Nie jest już zjawiskiem do podziwiania, ale funkcjonuje jako przestrzeń dla działań samego widza-współkreatora. Stąd też niegdysiejszy widz, którego zadaniem było odczytanie komunikatu, w teatrze postdramatycznym często sam ten komunikat konstruuje.

W ramy badań Lehmanna, który tylko na marginesie swoich rozważań wspomina o rozwoju cyberteatru, należałoby dziś włączyć także szereg pytań o sposób wykorzystania Internetu dla działań teatru. Jak dowodzi wiele z przeprowadzonych w wirtualnej przestrzeni spektakli, postęp technologiczny nie musi uniemożliwiać tej wspominanej przez Lehmanna i Fischer-Lichte partycypacji, będącej zasadą działania teatru. W przypadku gdy nie mamy do czynienia jedynie z odtworzeniem rejestracji spektaklu-zdarzenia, czyli przedstawieniem mediatyzowanym, lecz z jego rozgrywaniem przy naszym udziale w wirtualnej przestrzeni, zostaje utrzymana w mocy kategoria liveness. Owszem, działania aktorów i widzów w takich przedsięwzięciach jak choćby „Facebook live performance” zostają przeniesione do innej przestrzeni, ale nadal są synchronizowane czasowo, co oznacza, że nadal umocowane są na zasadzie autopojetycznej pętli feedbacku. Innymi słowy, mimo wyraźnego dystansu przestrzennego, zostaje zachowana autozwrotność komunikacji. W tradycyjnie rozumianym teatrze, to znaczy w takim, gdzie w tym samym miejscu (w przestrzeni rzeczywistej) o tym samym czasie spotykają się aktorzy i widzowie, zachodzi interakcja między obiema stronami. Komunikacja między aktorami i widzami odbywa się na zasadzie sprzężenia zwrotnego - zachowania aktorów wpływają na pu- 
bliczność, ta z kolei za każdym razem wpływa na to, co dzieje się z aktorem na scenie, nawet jeśli tylko szepce lub wierci się na krześle. Jak reasumuje Fischer-Lichte [2008: 58]:„To, co robią aktorzy, ma zawsze wpływ na widzów, zaś to, co robią widzowie - na aktorów i na innych widzów. W tym sensie można powiedzieć, że przedstawienie zaczyna się i jest sterowane przez samozwrotną i bezustannie zmieniającą się pętlę feedbacku. Dlatego jego przebiegu nie da się ani z góry zaplanować, ani przewidzieć".

\section{Cyberteatr $-\mathbf{2 b} \ldots$ or not $\mathbf{2 b}$...}

Doskonałą egzemplifikacją dla opisywanego przez niemiecką badaczkę mechanizmu nieustająco zmieniającej się i nieprzewidywalnej w swoim działaniu pętli feedbacku są przedstawienia odbywające się w wirtualnej przestrzeni, zwłaszcza pierwsze próby zainscenizowania teatru w Internecie, których powodzenie częstokroć zależało $\mathrm{w}$ większej mierze od możliwości technicznych niż od przygotowania i zaangażowania uczestników. Patrząc z perspektywy czasu na historię teatru w sieci, nie można mieć wątpliwości, że dość szybko otworzył się on na możliwości, jakie stwarzało przed nim nowe medium - wtedy będące jeszcze w powijakach.

Pierwsza premiera internetowa odbyła się 12 grudnia 1993 r. za pośrednictwem IRC (Internet Relay Chat), lecz z powodu problemów technicznych nie została w pełni zrealizowana. Niemniej internetowa inscenizacja Hamleta, opatrzona wymownym tytułem HAMNET, rozpoczęła „ekspedycje" teatru w głąb sieci. Stuart Harris - pomysłodawca i twórca projektu - do udziału w spektaklu zaprosił zarówno aktora Royal Shakespeare Company lana Taylora, jak również internautów z całego świata. Ostatecznie siedemnaścioro aktorów, czatując ze sobą, odgrywało, a raczej trawestowało Hamleta, który w wersji Harrisa został sprowadzony zaledwie do osiemdziesięciu linijek tekstu, kolejno kopiowanych przez uczestników do okna czatu z przesłanego im wcześniej, przygotowanego przez Harrisa skryptu. Tekst HAMNETA składał się z dowolnie wybranych fragmentów dramatu, wplecionych pomiędzy wersy emoticonów, ale też spontanicznych komentarzy internautów, wielokrotnie wychodzących ze swojej roli. Tomasz Kubikowski, który w roku 1996 na łamach „Didaskaliów”, tłumacząc jeszcze wtedy czytelnikom znaczenie poszczególnych emoticonów, pisał: 
Jednak był to Hamlet osobliwy. W całości sprowadzony do 80 linijek tekstu i oto, jak wyglądał w nim Wielki Monolog:

$<$ hamlet $>2 \mathrm{~b}$ or not $2 b .$.

$<$ hamlet $>$ Hmmmmmmmmmmmm...

$<$ hamlet $>$ :-( Bumm-errrr!!

$<$ hamlet> Ooops, here comes Ophelia

*-Enter Ophelia

„2b" czyta się po angielsku „two b”, więc tak samo jak „to be” - „być” (albo nie być). Następuje seria niezadowolonych mruknięć i zacukań, po czym wchodzi ( ${ }^{*}$-Enter") Ofelia; zapisane tak jak wyżej, stanowi to automatyczny komunikat, pojawiający się wtedy, kiedy jakiś nowy użytkownik włączył się właśnie do kanału. Podobnych zabaw jest tu bez liku: Hamlet radzi następnie Ofelii, żeby ta przełączyła się raczej na kanał "klasztor" („Oph: suggest u / JOIN \#nunnery"). Ona reaguje zdziwieniem: :-O. [Kubikowski 1996: 7]

Kubikowski, choć zaciekawiony pomysłem Harrisa, oceniał wydarzenie z dużą rezerwą, uznając, że uczestnicy premiery „bawili się, jak widać, samym medium swego kontaktu" [Kubikowski 1996: 7]. Jest pewna słuszność w tej obserwacji - trudno przecież zakładać, że uczestnicy projektu byli zaciekawieni bardziej akcją dramatu niż technologicznymi aspektami przeprowadzenia cyberpremiery tego rodzaju. Można również przypuszczać, że to właśnie możliwość interakcji, jaką stworzyła wirtualna przestrzeń, stała się przyczyną spontanicznych komentarzy internautów-aktorów, wykraczających poza przesłany im scenariusz. Próba ujęcia przedstawienia w ramy scenariusza narzuconego internautom przez reżysera i jednoczesne zniwelowanie ich roli do de facto technicznej czynności polegającej na kopiowaniu gotowych fraz nie wytrzymała konfrontacji z pragnieniem nieskrępowanej aktywności. Wirtualna scena stała się miejscem niekontrolowanych komentarzy, w tym, jak zauważył Ulf Otto [2013: 93] , "niewybrednych dowcipów [...] mniej lub bardziej inteligentnych i ironicznych wariacji z materiałem, samym procesem inscenizacji, czy w ogóle teatrem". Ostatecznie jednak projekt został przerwany nie przez łamiących scenariusz internautów, a z powodów awarii sieci, która skutkowała tym, że w trakcie spektaklu z czatu zniknął reżyser kontrolujący przebieg projektu.

Jeśli wspominam tę pierwszą próbę odegrania teatru w Internecie, to przede wszystkim dlatego, aby wskazać, jak szybko teatr sięgnął po nowe środki wyrazu, pojawiające się wraz z początkiem ekspansji nowego medium, i jak próbował zaadaptować je na użytek sztuki inscenizacji. Odno- 
towanie tego faktu jest ważne już choćby z tego względu, że dla wielu widzów, ale także dla samych reżyserów, Internet nadal wydaje się medium niepasującym do sztuki dramatycznej, w tym sensie, że narzędzia oferowane przez masowe medium (adresowane do odbiorcy egalitarnego) jawią się jako dalece nieadekwatne wobec teatru rozpatrywanego w kategoriach rozrywki elitarnej. Przesłanki dla polemiki z taką perspektywą z wielu względów wydają się oczywiste, dlatego nie będą tutaj rozpatrywane. Na marginesie warto zaznaczyć, że współczesny teatr, niekiedy sprawiający wrażenie wręcz „przeładowanego” mediami, zdążył już przyzwyczaić widza do technologicznych eksperymentów - użycia kamer i mikroportów, tworzenia scenografii jedynie za pomocą projektorów i strumieni światła czy transmisji live. Oswoił go również z wykorzystaniem na scenie czatu, skype'a i różnego rodzaju aplikacji internetowych towarzyszących rozwojowi nowych mediów. Komentowanie sposobów wykorzystania poszczególnych technologii nie ma tu większego sensu, tym bardziej że wiele $z$ nich istnieje w teatrze niemalże od czasów ich wynalezienia (wystarczy wspomnieć choćby eksperymenty świetlne Maxa Reinhardta i projekcje w teatrze Erwina Piscatora w latach dwudziestych XX wieku).

Tym jednak, na co warto zwrócić uwagę, zwłaszcza w kontekście powyższych spostrzeżeń, jest sposób reagowania widzów, m.in. krytyków, nie tylko na coraz to nowsze eksperymenty internetowe w teatrze, ale także na projekty, w których - jak mogłoby się wydawać - możliwości cyberprzestrzeni znajdują zastosowanie dość anachroniczne i nie powinny budzić większych emocji. Za przykład może tu posłużyć spektakl Tomasza Bazana I /figenia, inscenizowany w styczniu 2012 roku w Teatrze Nowym w Łodzi. Jeśli dziś mówi się jeszcze o spektaklu Bazana, to głównie w kontekście towarzyszącej premierze transmisji online, którą oglądało ponoć około czterech tysięcy internautów. Dyrektor Teatru Nowego Zdzisław Jaskuła nie krył, że decyzja o transmisji podyktowana była względami marketingowymi. W rozmowie z Jackiem Cieślakiem, opublikowanej na łamach „Rzeczpospolitej”, Jaskuła porównywał transmisje online spektaklu do oglądanych i przeżywanych zbiorowo transmisji meczy piłkarskich albo teledysków przyciągających uwagę publiczności. „Myślę, że to dobry sposób na prezentację teatru, tam gdzie nie ma warunków do grania lub jest to zbyt kosztowne. [...] Prezentacjom mogłyby towarzyszyć rozmowy z aktorami, reżyserem. Można mieć nadzieję, że z takiego spotkania wyniknie potem wizyta w naszym teatrze i zdobędziemy nowych widzów. [...] Za ogłoszenie w prasie anonsujące spektakl zapłacilibyśmy więcej. A przy okazji mamy zapis spek- 
taklu do archiwum oraz prezentację DVD, którą wysyła się zwyczajowo na festiwale bądź z myślą o gościnnych występach" - mówił Jaskuła. Trafne wydają się obserwacje dyrektora łódzkiej sceny i powodzenie transmisji online jest także w jakimś sensie oczywiste. $Z$ drugiej jednak strony popularność projektu może nieco zadziwiać, bo przecież transmisja spektaklu online nie jest przedsięwzięciem nadzwyczajnym ani też nowym dla polskiego widza; pierwszą tego typu transmisję można było oglądać już w roku 2006'.

\section{"HAMNET" ==== Shakespeare's play adapted for irc}

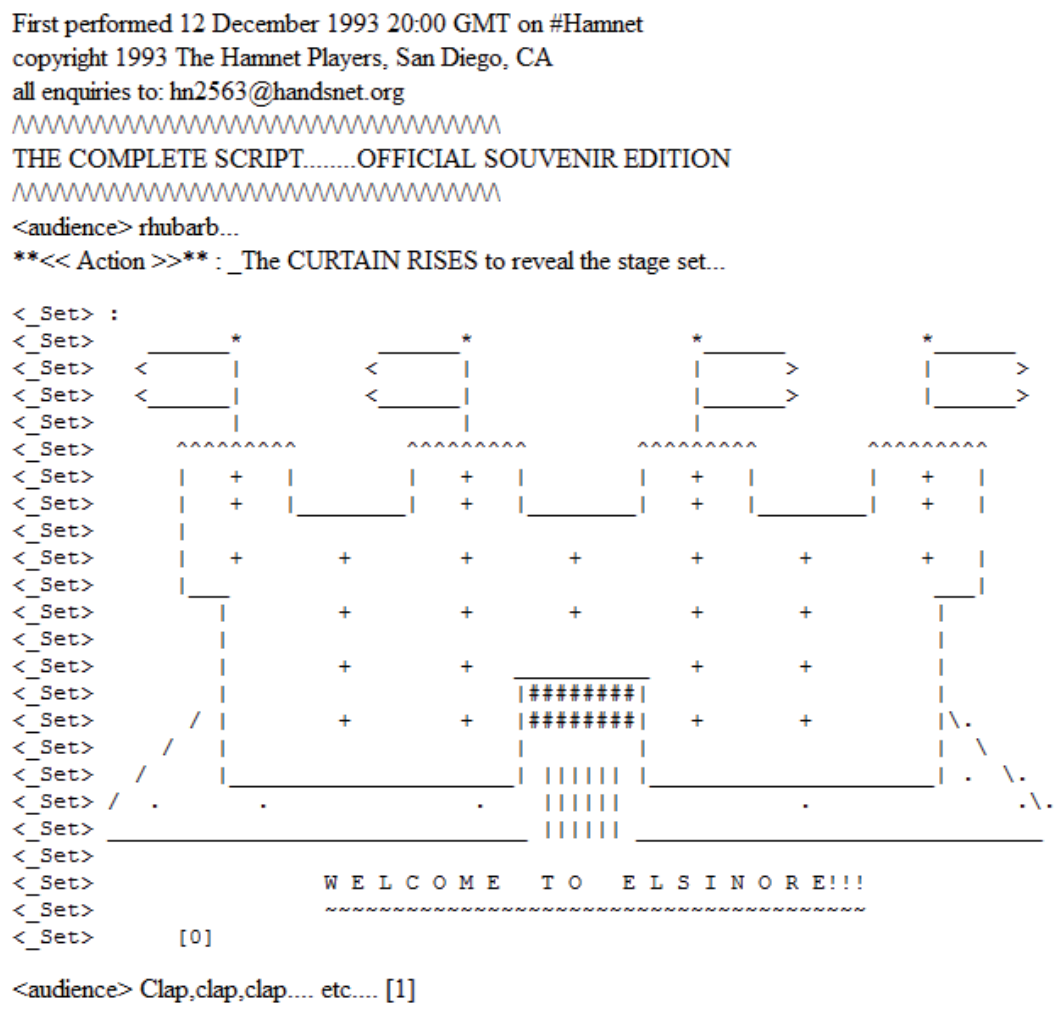

Rys. 1.,„Scenografia" otwierająca pierwszą scenę HAMNETA. Źródło: http://www.hambule.co.uk/ hamnet/hscript.htm [dostęp: 23.03.2013]

1 Chodzi tu o spektakl ze Starego Teatru w Krakowie - Brzeg-Opole w reżyserii Wojciecha Majcherka. Można także wskazać w tym miejscu kilka innych tego typu transmisji, na przykład premierę Boskiej! z Krystyną Jandą w roli głównej oraz projekt Internetowy Teatr Internetowy TVP dla szkół prowadzony przez Teatr Telewizji. 
Przyglądając się ekspansji teatru w wirtualnej przestrzeni, można dojść do wniosku, że medium Internetu stanowi dla teatru niewyczerpany rezerwuar nowych środków wyrazu, aczkolwiek dla wielu scen nadal pozostaje terra incognita. Poniekąd dowodzą tego właśnie transmisje spektakli online w polskich teatrach, traktujących przekaz internetowy jako swoistą nowinkę technologiczną. Pozostawiając na boku domysły o kierunkach rozwoju strategii wizerunkowych teatrów, tworzonych z wykorzystaniem Internetu, oraz artystycznych reperkusjach tych działań (także na scenach polskich), trzeba poczynić w tym miejscu kilka uwag, syntezujących dotychczasowe spostrzeżenia. Otóż dla szeroko pojętych zdarzeń teatralnych przeniesienie akcji dramatycznej do wirtualnej przestrzeni nie podważa zasady teatralnej komunikacji. Owszem, zanika tradycyjne rozumienie sceny wraz z grającym na niej aktorem oglądanym przez publiczność skrytą w mroku widowni, zwłaszcza że w symulacji wirtualnego teatru widz częstokroć zyskuje większą autonomię w kreowaniu sensów zdarzeń. Fenomen tego spotkania rzeczywistości z wirtualnością niezwykle trafnie oddaje Patrice Pavis, nadal nazywający różnego rodzaju mechaniczne reprodukcje „żywymi spektaklami":

Czy powinniśmy się obawiać, że ludzki byt nie będzie już w centrum dzieła, że media zaprowadziły nas do postczłowieczeństwa i postdramatyczności, że podmiot (twórca i odbiorca) rozpłynął się na panelu kontrolnym i stał się zwykłym programistą na usługach komputerów? W żadnym razie! Gdy ten zaprogramowany i programujący podmiot zaczyna oceniać związki między znakami i przedmiotami, różnice między żywym i tym, co w inercji, gdy tylko poddaje się fikcyjnej inkarnacji w swoje kreacje, wówczas na nowo staje się inscenizatorem. Ponownie staje się człowiekiem, ponieważ popełnia błędy, renegocjuje moc i iluzję teatru bez uprzedzeń i prawa do wyłączności. Oczywiście odtąd zdaje sobie sprawę z nowych darów mediów i wynikającej z tego rekonfiguracji teorii postbrechtowskich i postsemiotycznych, zwłaszcza w zakresie opozycji signifiant-signifié, materialność - informacja niematerialna [Pavis 2011: 181-182].

Pavis niejako łagodzi konflikt między tym „żywym” teatrem a teatrem zdominowanym przez media, czy też przeniesionym do sieci, podkreślając, że "Rzeczywista obecność aktora na scenie nie jest niezbędna dla widza” [Pavis 2011: 188]. Idąc za francuskim badaczem, można dodać, że i rzeczy- 
wista obecność widza nie jest konieczna w procesie teatralnej komunikacji, w końcu także sama scena - rozumiana jako namacalna przestrzeń - nie jest warunkiem koniecznym dla zaistnienia zdarzenia teatralnego. Od dwóch dekad - mierząc czas od pierwszej internetowej premiery HAMNETA - przekonują nas o tym coraz liczniejsze projekty teatralne, nie tylko wykorzystujące, ale wręcz opierające się na zaawansowanych technikach multimedialnych lub przeznaczone tylko i wyłącznie do odbioru internetowego.

Można pokusić się przy tym jeszcze o pewną dygresję, pomocną w zrozumieniu fenomenu popularności wielu z omawianych tutaj projektów teatralnych. Nie trzeba wykazywać się szczególną spostrzegawczością, aby zauważać, że znaczna część, jeśli nie większość spektakli przeniesionych do sieci bądź realizowanych za pomocą na przykład narzędzi social media to inscenizacje dzieł klasycznych, rzadko kiedy wykraczających poza ścisły kanon literacki - wręcz kanon lektur szkolnych. Ta obserwacja dotyczy zarówno pierwszych inscenizacji z lat dziewięćdziesiątych ubiegłego wieku, jak również najnowszych produkcji i wszystko wskazuje na to, że nieprędko ulegnie dezaktualizacji. Operowanie literackim kanonem wydaje się z wielu względów oczywiste. Literatura klasyczna, co potwierdza choćby przypadek Shakespeare'a, jest egalitarna². To stwierdzenie odnosi się oczywiście nie do znajomości dzieł literackich, lecz do znajomości samego kanonu. Dalece naiwne byłoby założenie, że treść, problematyka lub choćby postaci Hamleta są powszechnie znane - oczywiście nie są, co nie oznacza, że sama postać Hamleta, będącego nie tylko ikoną teatru, ale wręcz ikoną kulturową, nie istnieje w powszechnej świadomości, nawet w świadomości osób nieuczestniczących czynnie w kulturze. Krótko mówiąc, tak zwane dzieło klasyczne, współtworzące kanon literacki, budzi szereg asocjacji, nawet jeśli jego treść jest widzowi obca. Dzieło takie w większości przypadków uruchamia sieć skojarzeń pozwalających osadzić widzowi dany tekst, spektakl, postać dramatyczną w określonym kontekście. Większość widzów udających się do teatru na premierę Hamleta spodziewa się zobaczyć duńskiego księ-

2 Teatr szekspirowski już z założenia przecież był teatrem masowym, przeznaczonym dla szerokiej rzeszy odbiorców, podobnie jak teatry ludowe w Niemczech i Austrii, grające sztuki Ferdinanda Raimunda i Johanna Nestroya dla publiczności złożonej z przedstawicieli wszystkich stanów od praczek, aż po samego cesarza. Podobne przykłady można jeszcze długo mnożyć, wskazując choćby hiszpańskie corrales de comedias, w których grywano najwybitniejszych autorów epoki, takich jak: Lope de Vega, Calderón de la Barca, Tirso de Molina; w końcu Carlo Goldoniego i Carlo Gozziego, autorów włoskiej commedia dell'arte, ale również i tragików greckich. 
cia z czaszką Yoricka w dłoni, wypowiadającego słynny monolog, z którego widzom pobrzmiewa w uszach jedynie fraza "być albo nie być", w końcu spodziewa się zobaczyć aktorów w strojach z epoki, wiernie deklamujących tekst Shakespeare'a. To jednak, jak wiele wersów słynnego monologu Hamleta widz pamięta, nie ma większego znaczenia, chodzi bowiem o samo stworzenie pewnych sieci odniesień.

W przypadku inscenizacji dzieł należących do literackiego kanonu lub po prostu powszechnie znanych, choćby w zarysie, widz posiada określony horyzont oczekiwań. Teatr zawsze sprawnie zarządzał tymi oczekiwaniami, częstokroć umyślnie je przełamując, celowo występując przeciwko nim, dając widzom to, czego ci najmniej by się spodziewali. Współczesne teatralne projekty internetowe w dużej mierze odwołują się do tego właśnie horyzontu oczekiwań widza, po to głównie, aby z nim igrać. Powodzenie wielu z premier w wirtualnej przestrzeni bazuje właśnie na elemencie zaskoczenia, gdy opowiadana widzowi historia wykracza poza horyzont jego wyobrażeń.

Nie przez przypadek więc Harris, planując pierwszą internetową premierę, sięgnął po Hamleta, a w kilka miesięcy później w ten sam sposób inscenizował również Makbeta. Wbrew pozorom wybór tekstów-ikon, za jakie można uznać oba dramaty Shakespeare'a, nie był bynajmniej wyborem aż tak nieoczywistym. Harris, a za nim dziesiątki innych reżyserów dokonujących podobnego co on wyboru, sięgnął po tekst powszechnie znany (także z licznych ekranizacji), przetłumaczony na kilkaset języków. Tym samym otworzył swój projekt na bardzo szerokie grono odbiorców, nie tylko reprezentujących różne kręgi kulturowe, ale również grupy wiekowe. W przypadku HAMNETA uczestnicy projektu nie musieli nawet wykazywać się szczególnymi kompetencjami językowymi, to znaczy nie musieli znać języka, w którym odbywał się spektakl, ponieważ ich interakcja polegała jedynie na wklejaniu w okno czatu przydzielonych im wersów. Co więcej, inscenizowanie tekstu klasycznego, będącego w rzeczywistości trawestacją, polegającą na dowcipnej grze z samym tekstem, jego zapisem w formie rozmowy na czacie, w której użyto specyficznego języka emotikonów, jak również żartobliwe przekształcenia dialogów, a przede wszystkim samo medium wykorzystane w tym projekcie ustanawiało całkiem nowe dzieło dla jego odbiorców i współtwórców. Reżyser uwspółcześnił Hamleta nie tylko na płaszczyźnie treści i języka, ale przede wszystkim formy. W pewnym sensie to właśnie sama forma przekazu stała się tutaj treścią. 


\section{Facebook live performance}

Podobny mechanizm jest uruchamiany w przypadku współczesnych spektakli i performansów wykorzystujących najnowsze możliwości Internetu, zwłaszcza popularne od niedawna platformy społecznościowe. Każda z nich dysponuje nieco innym repertuarem funkcji stwarzających możliwość ich zaadaptowania na potrzeby teatru, podobnie jak dla wielu innych działań artystycznych czy stricte marketingowych. Korzyści płynące dla twórców decydujących się na skierowanie swojej wypowiedzi do użytkowników portali takich jak Twitter czy Facebook są oczywiste. Nie chodzi przy tym jedynie o to, że platformy te są dziś chyba najbardziej kompleksowym narzędziem umożliwiającym kreowanie wizerunku, ale także o to, że instytucje takie jak teatr mogą korzystać z tych narzędzi zarówno dla działań marketingowych, jak i kreując wypowiedź o znaczeniu artystycznym.

Interesującym przykładem takiego wykorzystania social media może być projekt wirtualnej sceny zapoczątkowany w roku 2011 przez Maxim Gorki Theater w Berlinie premierą Effi Briest. Internetowa scena nie miała bynajmniej za zadanie transmitować live spektaklu teatralnego (podobnie jak w przypadku łódzkiej / /figenii), co mogłaby sugerować nazwa projektu. Wirtualna scena Maxim Gorki Theater jest bowiem sceną, na której spektakl powstaje przy udziale zarejestrowanych wcześniej na profilu teatru uczestników-widzów, ingerujących w spektakl (oczywiście do pewnego stopnia). Ów spektakl odgrywany jest bezpośrednio na Facebooku dzięki ciągłemu aktualizowaniu profilu teatru i może być oglądany oraz współtworzony tylko przez tych użytkowników Facebooka, którzy w odpowiednim momencie zgłosili chęć swojego uczestnictwa w premierze, czyli dołączyli do fanpage'u teatru, tym samym stając się współreżyserami, ale też aktorami w inscenizacji XIX-wiecznej powieści Theodora Fontane Effi Briest. Nie oznacza to jednak, że widzowie wcielają się w konkretne role, tak jak to było w HAMNECIE, wręcz przeciwnie - widzowie pozostają sobą, występują nawet pod swoim prawdziwym imieniem i nazwiskiem, uczestnicząc w grze poprzez swój profil na Facebooku. Granice ich ingerencji w akcję sceniczną są jednakże określone przez regulamin, będący jednocześnie swego rodzaju „instrukcją obsługi" projektu. Zamieszczony na stronie teatru regulamin nie jest szczególnie restrykcyjny, twórcy projektu formułują bowiem jedynie trzy zasady, o których przestrzeganie proszą uczestników: 
Aby niczego nie przegapić, regularnie aktualizujcie Państwo swoją stronę;

Proszę nie przerywać przedstawienia komentarzami albo linkami, jeśli nie jesteście Państwo o to proszeni;

Ale proszę czynić to za każdym razem, kiedy zostaniecie Państwo jako publiczność - poproszeni o pomoc.

Udział widzów w spektaklu ma więc określone ramy i sprowadza się do aktywności w wyznaczonych momentach, co ma zapewne zapobiec przerywaniu akcji przez niekontrolowaną ekspresję uczestników.

Jednorazowo odegrany spektakl, opatrzony tytułem EFFI BRIEST 2.0, polegał na rozgrywaniu akcji dramatycznej na profilu Facebooka: każdy z aktorów, a raczej każda z postaci dramatycznych, za pomocą swojego konta prowadziła na Facebooku rozmowę z pozostałymi postaciami, korzystając z takich funkcji oferowanych przez portal, jak umieszczanie zdjęć, filmów, wysyłanie wiadomości czy przyznawanie "lajków". W tej akcji dramatycznej publiczność (znajdująca się poza budynkiem teatru) w odpowiednich momentach współkomentowała dokonywane przez bohaterów decyzje, podpowiadała im rozwiązania lub wręcz dokonywała za nich wyborów. I tak, gdy główna bohaterka wychodzi za mąż, przedstawia widzom trzy ewentualne kreacje ślubne, lecz to publiczność, nie Effi, decyduje o tym, w co ubierze się panna młoda. O pomoc przy w wyborze ubioru prosi publiczność sama matka Effi, która wykraczając poza ramy opowieści, zwraca się bezpośrednio do publiczności z prośbą o głosowanie na najlepszy kostium. Każda z decyzji publiczności, zarówno w tej, jak i w innych kwestiach, zostaje uwzględniona, co nie oznacza jednak, że zostaje przyjęta przez bohaterów bezkrytycznie. Już choćby wybór sukni ślubnej dokonany przez wirtualną publiczność niekoniecznie musi spodobać się przyszłemu małżonkowi czy matce Effi, którzy swoją aprobatę lub dezaprobatę wyrażają znów za pomocą przycisku "Lubię to". Publiczność decyduje zresztą nie tylko w tak błahych kwestiach jak wybór kostiumu, często musi pomóc bohaterom podjąć niezwykle trudne decyzje lub dosłownie podejmuje je za nich, nawet jeśli są to tak zwane „życiowe wybory". Widzowie rozstrzygają nawet w sprawie zamążpójścia Effi - to oni mianowicie wyrażają zgodę na jej ślub z Innstettenem. Propozycja ślubu zostaje wysłana przez kandydata jako zapytanie, a decyzja zapada w wyniku rozstrzygnięcia ankiety przeprowadzonej właśnie wśród publiczności. 


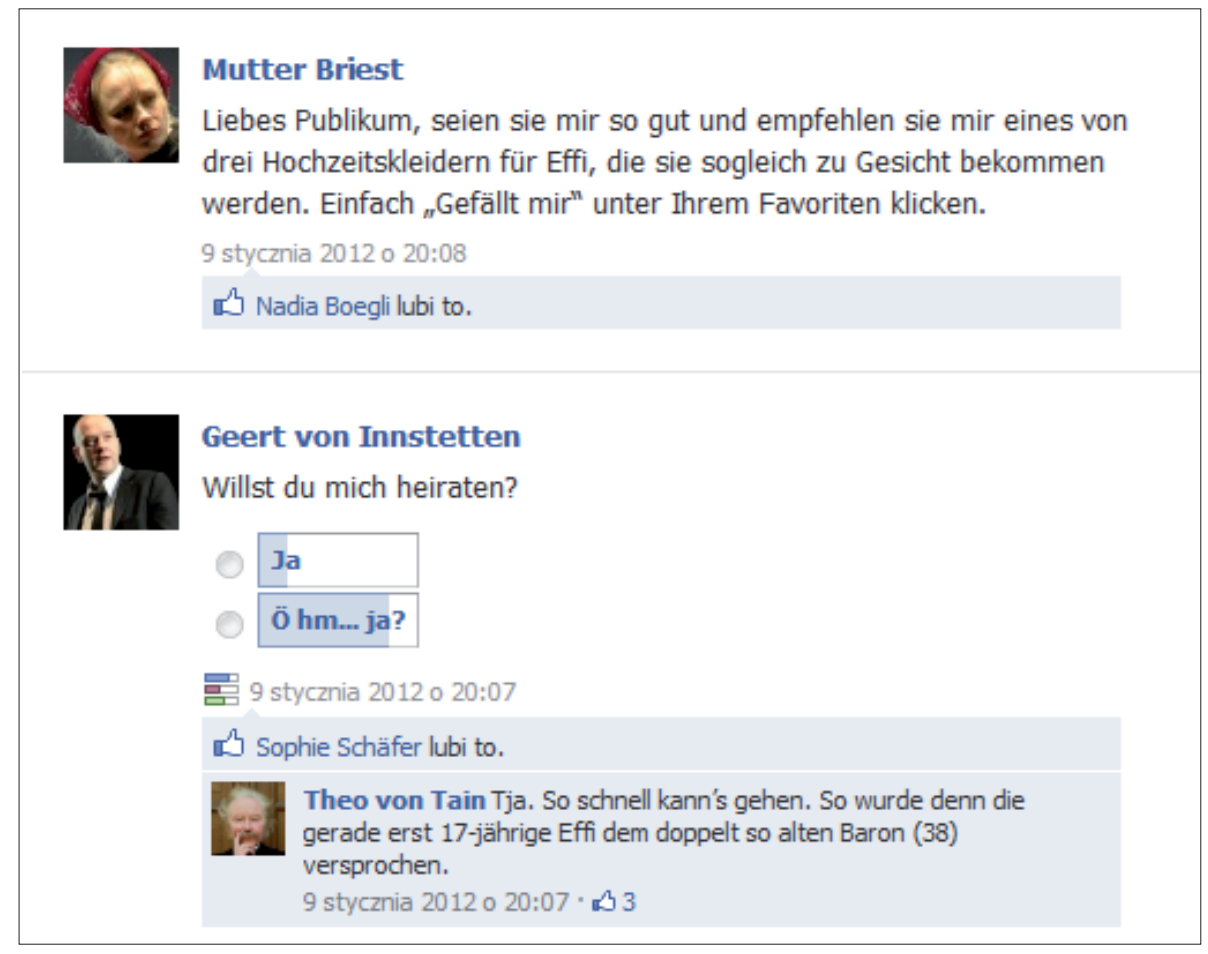

Jak widać, twórcy tej pierwszej premiera w social media wykorzystują poszczególne funkcje Facebooka zgodnie $z$ ich przeznaczeniem, dokładnie odwzorowując ich użycie w świecie rzeczywistym przez rzeczywistych użytkowników. Bohaterowie EFFI BRIEST 2.0 już po zaręczynach tworzą wydarzenie "Ślub" i także za pomocą funkcji „zaproś” wysyłają zaproszenie do wszystkich swoich znajomych (innych postaci sztuki oraz zalogowanych widzów-uczestników). Wkrótce na profilach małżonków pojawiają się ślubne zdjęcia, komentarze, życzenia i „lajki”. Małżonkowie uaktualniając swoje statusy, Effi przeprowadza się do domu męża i informuje znajomych o zmianie miejsca zamieszkania, podczas gdy dumny małżonek prezentuje zdjęcia nowych mebli. Obserwatorzy mogą zatem śledzić zapis ich życia, a z czasem rozpad ich małżeństwa. W życiu Effi pojawi się bowiem przystojny adorator Major von Crampas (na swoim profilu występuje jako Ma Jor Crampas), a losy obojga splotą się oczywiście także dzięki ingerencji publiczności, która kolektywnie, za pomocą komentarzy na profilu bohatera, dopisuje kolejne zdania miłosnego listu do Effi. To właśnie listy miłosne Crampasa do Effi, pisane spontanicznie przez publiczność, staną się 
przyczynkiem do tragedii. Major, podobnie jak wielokrotnie robiła to Effi, zwraca się do widzów z bezpośrednią prośbą o pomoc przy pisaniu listu, następnie układa ów miłosny liścik z wybranych propozycji - komentarzy zamieszczanych przez internautów pod jego postem.

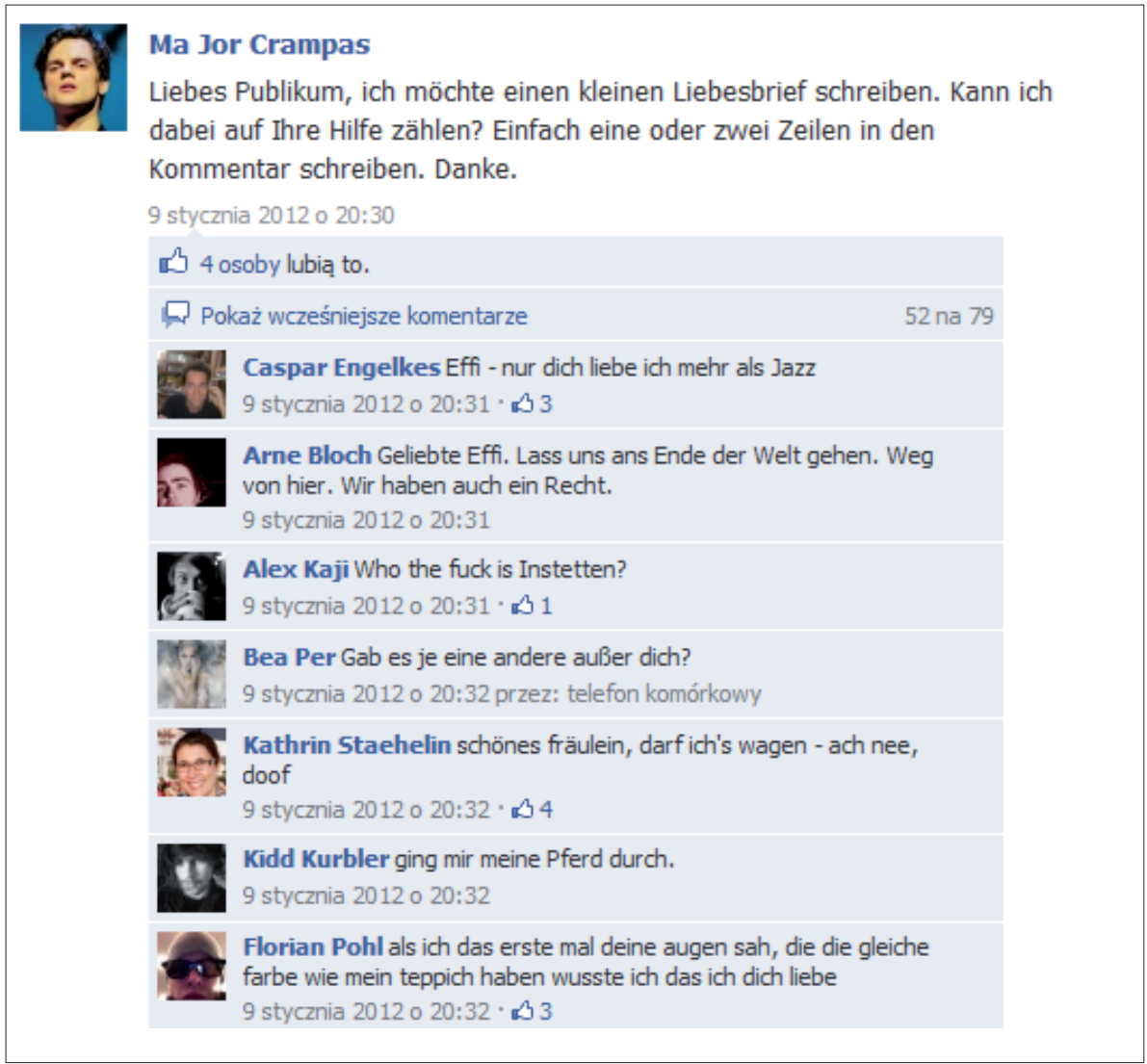

Tym sposobem w niespełna dwadzieścia minut od opublikowania apelu o pomoc Crampas przedstawia swoim pomocnikom gotowy list, który być może daleki jest od konwencji epistolarnego wyznania XIX-wiecznego kochanka, ale można podejrzewać, że nastolatka, jaką jest Effi, będzie pod wrażeniem tego dowodu miłości. To właśnie list napisany przez publiczność i odczytany przez męża Effi stanie się przyczyną rozpadu jej małżeństwa. Tuż po lekturze miłosnego wyznania Crampasa na naszych oczach zazdrosny mąż przegląda bowiem kolejne oferty internetowych sklepów, oferujących zakup broni. Epilog, jak można się domyślać, jest tragiczny - In- 
nstetten w honorowym pojedynku zabija Crampasa, a następnie rozwodzi się z Effi.

EFFI BRIEST 2.0 bazuje na wykorzystaniu poszczególnych funkcji Facebooka w taki sposób, że możliwe staje się prowadzenie dzięki nim spójnej narracji. Jest to narracja niezwykle syntetyczna - w trakcie trwającego około pięćdziesięciu minut spektaklu zostają pominięte wątki poboczne, a spośród ponad trzydziestu bohaterów powieści poznajemy tylko głównych protagonistów. Jeśli jakieś zdarzenie potrzebuje umocowania w przeszłości bądź historii biegnącej obok głównego wątku, zostaje ono streszczone w komentarzu któregoś z bohaterów, ale bez przesadnej wylewności czy zbędnych szczegółów. Niekiedy skróty są radykalne - kilkadziesiąt stron powieści zostaje przedstawionych w zaledwie kilku zdaniach, co jednak nie wprowadza niezręcznych niejasności i niedopowiedzeń. Skrócona historia Effi Briest pozostaje nadal czytelna, także dla uczestników nieznających tekstu.

Można by dyskutować, jak dalece projekt berlińskiego teatru jest interaktywny. Udział wirtualnej publiczności w kreowaniu zdarzeń jest z góry zaprogramowany i poniekąd złudny - widz zostaje dopuszczony do głosu w określonych momentach, a wybory są wyborami dokonywanymi pomiędzy z góry ustalonymi możliwościami. Naruszenie zatem pewnej ramy wydarzeń jest niewykonalne, czego najlepszym przykładem ankieta, mająca zdecydować o zamążpójściu Effi. Innstetten składający Effi ofertę małżeństwa, jednocześnie oddający decyzje w ręce publiczności, w ogóle nie przewiduje opcji odmowy. Publiczność może wybrać jedną spośród dwóch odpowiedzi, przy czym obie są pozytywne. Zachodzi między nimi ta tylko różnica, że jedna jest odpowiedzią pewną („tak”), a druga wyraża pewne wahanie („o hm... tak?”). Twórcy EFFI BRIEST 2.0 zachowują więc bezpieczny dystans, pozwalają odczuć widzom, że są oni realnymi współtwórcami opowieści, aczkolwiek wiele z ich decyzji sprawia wrażenie pozornych. Przykładowo nie da się odrzucić oświadczyn, uniemożliwiając tym samym zaręczyny Effi, bo oznaczałoby to anulowanie całej opowieści, rozpoczynającej się właśnie z chwilą zaręczyn. Z drugiej jednak strony, obie odpowiedzi, będące w istocie różnymi sposobami wyrażenia zgody na małżeństwo, jak również oddanie decyzji o zamążpójściu Effi w ręce publiczności, odzwierciedlają sytuację, w której bohaterka się znalazła, zarówno tę rodzinną, jak i społeczną. W powieści Fontane'a - przypomnijmy, że jej akcja rozgrywa się pod koniec XIX wieku - siedemnastoletnia Effi nie ma większego wpływu na swoje losy. Jej zgoda na małżeństwo jest symboliczna, bo o jej życiu u boku, 
wprawdzie o wiele starszego, ale jednak bogatego i wpływowego Innstettena, decydują rodzice. Tak jak w powieści Fontane'a, tak w EFFI BRIEST 2.0 bohaterka stoi nie przed wyborem, lecz przed koniecznością zaakceptowania cudzej decyzji. W tym przypadku jest to decyzja widzów i zapada ona nie po to, aby uszczęśliwić Effi, ale po to, by zadowolić spragnioną wrażeń publiczność.

Odrębną kwestią pozostaje to, że sam projekt internetowej sceny, wprowadzony przez jej twórców w takim dokładnie kształcie, jest dość przewrotny. Trudno oprzeć się pokusie odczytywania go jako komentarza społecznego, w gruncie rzeczy krytycznej wypowiedzi na temat współczesnego cyberspołeczeństwa. Maxim Gorki Theater nigdzie otwarcie nie zdradza takich intencji, aczkolwiek przeprowadzony eksperyment teatralny jest przecież swego rodzaju socjologicznym komentarzem rzeczywistości. Takie odczytywanie podsuwa również lektura powieści, uchodzącej przecież za jedną z najostrzejszych diagnoz obłudnej moralności współczesnego autorowi społeczeństwa, przede wszystkim kręgów burżuazji, niemalże handlującej małżeństwami. W tym środowisku tylko intratne związki zyskiwały akceptację, którą dziś symbolicznie wyrazilibyśmy za pomocą przycisku „lubię to". Analogiczną krytykę społeczeństwa można skonstruować, opierając się na projekcie berlińskiego teatru: publiczność obserwująca z dystansu losy Effi, podobnie jak pruska socjeta sportretowana w powieści, decyduje o jej losach i świetnie się bawi, podglądając życie małżonków i miłosne uwikłanie dziewczyny. „Facebookowe życie” Effi niewiele pewnie różni się od życia prowadzonego na tablicach większości uczestników projektu. Ekshibicjonizm Effi i jej męża sam w sobie już w niewielkim stopniu zadziwia, podobne streszczenie życiorysu, wraz z uwzględnieniem niezwykle osobistych, wręcz intymnych jego przejawów, przedstawia znaczna część użytkowników Facebooka. Informowanie o zmianie statusu związku, publiczne wyznania miłości lub wręcz przeciwnie, nienawistne groźby, żale i oficjalne zakończenie znajomości, a także zdjęcia z wakacji i wesela, zdjęcia z rodziną i przyjaciółmi, osobiste zwierzenia - wszystkie z nich stają się częścią opowiadanej na Facebooku historii Effi, tak jak stają się częścią życia milionów użytkowników social media, szukających w sieci miejsca swojej ekspresji, ale też społecznej akceptacji, wyrażonej symbolem podniesionego kciuka. Konkluzja może być wyjątkowa gorzka, jeśli uświadomić sobie, że tak jak decyzjami Effi kierowało otaczające ją towarzystwo, tak decyzjami wielu posiadaczy kont na Facebooku kieruje opinia towarzystwa "lajkującego" kolejne posty. 
Tego typu odczytań brak jednak w opiniach internautów, biorących udział w premierze, co zresztą nie dziwi. O wiele bardziej zaskakujące jest to, że EFFIE BRIEST 2.0, pomyślana jako działanie promocyjne, wzbudziła entuzjazm krytyki, rozpatrującej internetową premierę w kategoriach estetycznych, podczas gdy w zamyśle jej twórców internetowa premiera miała być akcją promocyjną prawdziwej premiery Effi Briest w reżyserii Jorinde Dröse, odbywającej się tydzień później już na prawdziwej scenie Maxim Gorki Theater w obecności aktorów i widzów. Dyrekcja teatru od początku traktowała projekt internetowy w kategoriach reklamy, mającej przyciągnąć do teatru przede wszystkim młodą publiczność, zapewne pałającą wyraźnym resentymentem do szkolnych lektur, w tym powieści Theodora Fontane. Paradoksalnie jednak to nie spektakl Dröse - raczej tradycyjnie pomyślany i daleki od formy sugerowanej przez internetową reklamę - wzbudzał zainteresowanie mediów i widzów, lecz towarzysząca mu akcja promocyjna. Co więcej, również EFFI BRIEST 2.0, nie zaś Effi Briest zebrała pozytywne recenzje, w pierwszej kolejności rozpatrujące potencjał estetyczny, nie zaś marketingowy całego projektu. W efekcie spektakl Dröse nie doczekał się nawet recenzji w czasopismach teatrologicznych, podczas gdy premierę EFFI BRIEST 2.0 odnotowała na swoich łamach większość niemieckojęzycznych dzienników, a nawet tygodników kulturalnych, a fragmenty inscenizacji nadal można oglądać na profilu i stronie teatru oraz YouTube. Sama premiera Effi Briest, która najwyraźniej nie wytrzymała konfrontacji z formą towarzyszącej jej promocji w Internecie, mimo wszystko okazała się sukcesem frekwencyjnym i to przede wszystkim wśród publiczności poniżej trzydziestego roku życia, co najprawdopodobniej zawdzięcza poprzedzającej ją facebookowej inscenizacji.

\section{Internet się liczy! Teatry w poszukiwaniu utraconej publiczności}

Rozwój social media, ich ekspansywna obecność w naszym codziennym życiu w naturalny sposób odciska się na działaniach wielu instytucji kultury, anektujących przestrzeń sieci dla różnych form swoich działań statutowych. Użycie nowych mediów przez te instytucje jest motywowane nie tylko estetycznie, ale - co wydaje się oczywiste - ma pomóc w konstruowaniu odkreślonego wizerunku i stać się narzędziem promocji lub implicite 
przemycać działania marketingowe. Tym, co zasługuje na szczególną uwagę, gdy mowa o coraz popularniejszej wśród instytucji kultury tendencji do udziału w procesie multiplikowania możliwości cyberprzestrzeni, jest fakt, że kreowane przez nich zdarzenia tworzą nową jakość wypowiedzi artystycznej, jak i strategii promocyjnej. Ich punktem wspólnym zaś jest dążenie do wykreowania takiej przestrzeni aktywności dla uczestników kultury, w której będą mogli zbudować wspólnotę - jednak nie tę będącą jedynie spisem znajomych na Facebooku, lecz tę będącą wspólnotą doświadczeń, odwołującą się do jednostkowego, ale i kolektywnego przeżycia. W takim też rozumieniu teatry próbujące włączyć widza w bezpośrednie działania poza obrębem klasycznie rozumianej widowni, choć eliminują możliwość bezpośredniego, fizycznego kontaktu między widzem i aktorem, paradoksalnie zbliżają ich do siebie. Wirtualna przestrzeń, przyznająca większą autonomię widzowi, nie tylko skłania, ale w wielu przypadkach zmusza go do przybrania roli współuczestnika zdarzeń i demiurga decydującego o rozwoju zdarzeń.

Bez wątpienia social media uruchomiły całą gamę możliwości bezpośredniej komunikacji, zakrojonej na szeroką skalę, w której zagwarantowana jest przestrzeń także dla indywidualnego odbiorcy, przez co teatry korzystające z tego typu narzędzi otworzyły się na widzów, w tym tych, którzy wcześniej byli poza ich zasięgiem. Próba zachęcenia widza do interaktywnego uczestnictwa w konkretnym projekcje, wręcz uczestnictwa w grze, w której on sam stanie się jednym z czynnych podmiotów, otwiera zatem nowe płaszczyzny komunikacji, ale i odkrywa nieoceniony potencjał marketingowy. Trzeba jednakże poczynić i tę uwagę, że powodzenie tego typu form promocji tylko po części wynika z podążania teatrów za ciągle oddalającym się horyzontem oczekiwań widza. Działania kreowane za pomocą choćby mediów społecznościowych przyciągają uwagę widzów także dlatego, że w wielu teatrach nadal są rzadkością. Na tle projektu, takiego jak choćby EFFIE BRIEST 2.0, a zatem przedsięwzięcia w niekonwencjonalny sposób wykorzystującego narzędzie social media, działania większości teatrów w mediach społecznościowych wyglądają mało spektakularnie, wręcz mogą sprawiać wrażenie zapóźnienia teatrów w wykorzystywaniu potencjału Internetu. Tę ostatnią uwagę można odnieść do instytucji kultury w ogóle ich obecność w Internecie jest bowiem zaprojektowana w dość konwencjonalny sposób, a konstruowane przez nie strategie marketingowe niewiele różnią się od strategii wykorzystywania Internetu jako narzędzia promocji przedsiębiorstw w każdym z możliwych sektorów gospodarki. Zastanawia- 
jący jest przy tym unik samych analityków i badaczy kultury, którzy nadal zdają się poświęcać niewystarczającą uwagę zarówno ekonomicznym, jak $i$ artystycznym aspektom funkcjonowania instytucji kultury, w tym szerzej omawianych tu teatrów, w sieci. Dla przykładu warto przywołać choćby wydane w roku 2011 przez Narodowe Centrum Kultury, w serii Kultura się liczy, kompendium Ekonomia kultury. Autorka tego obszernego opracowania Ruth Towse - skrupulatnie przedstawia najistotniejsze relacje ekonomiczne zachodzące w przestrzeni organizacji i działalności kulturalnej, rozpoczynając od historii ekonomii kultury, analizy rynku, kosztów i korzyści, przez organizację rynków pracy artystów, praw własności, aż po problematykę popularnych ostatnio tak zwanych przemysłów kreatywnych. Próżno jednak szukać w kompendium tym, aspirującym do bycia aktualnym opracowaniem najnowszych trendów w zakresie ekonomii kultury, refleksji na temat ekonomicznym aspektów działalności instytucji kultury w przestrzeni wirtualnej. Najobszerniejszy passus rozważań poświęcony w książce bezpośrednio znaczeniu Internetu dla szeroko pojętej działalności kulturalnej zamyka się zaledwie w kilku zdaniach, które współczesnego użytkownika sieci i odbiorcę kultury mogą wprawić w zakłopotanie. Towse komentuje udział Internetu w kulturze następująco:

Internet jest najnowszym nośnikiem dóbr kultury, powstałym w wyniku rewolucji cyfrowej oraz rozpowszechniania się tanich komputerów osobistych. W momencie, gdy piszę te słowa, internet jest dopiero u początku drogi, jeśli chodzi o tworzenie treści kultury (nie wątpię, że w chwili wydania tej książki opinia ta stanie się już całkowicie nieaktualna). Zaczynem zmian są blogi, platformy społecznościowe, takie jak Facebook oraz Youtube, a także gazety internetowe. Internet odgrywa również ogromną rolę w reklamie oraz upowszechnianiu konsumpcji za pomocą sieci. Prawdziwym przełomem jest Wikipedia, która udostępnia zasoby encyklopedyczne całkowicie za darmo. Rewolucja cyfrowa i konsekwencje istnienia internetu są dyskutowane w poszczególnych rozdziałach części IV, ale dotychczas prowadzone przez ekonomistów kultury badania nad rolą internetu są na razie zbyt ubogie, by poświęcić temu zagadnieniu odrębny rozdział. [Towse 2011: 125]

Autorka odnotowuje istnienie i wpływ Internetu na ekonomię i organizację kultury jako takiej tylko mimochodem, a jej stwierdzenia są wyjątkowo oględne. Owszem, we wspomnianym rozdziale poświęconym 
przemysłom kreatywnym Towse ponownie omawia pewne formy udziału Internetu w tworzeniu kultury, ale jest to omówienie bardzo wybiórcze i pobieżne, w zasadzie niewykraczające poza problem piractwa, kontroli nielegalnych produktów i naruszeń praw autorskich, głównie w kontekście przemysłu muzycznego. Można polemizować z twierdzeniem, że w roku 2010 „internet jest dopiero u początku drogi, jeśli chodzi o tworzenie treści kultury", czy też wyjątkowo asekuracyjnym spostrzeżeniem, że „badania nad rolą internetu są na razie zbyt ubogie". To, co jeszcze zadziwia podczas lektury Ekonomii kultury, to nie tylko niedocenienie, ale wręcz pominięcie całego szeregu aspektów ekonomicznych i organizacyjnych wynikających z rewolucji internetowej, jaka ogarnęła również instytucje kultury. Odrębną kwestią pozostają tu zagadnienia stricte socjologiczne i estetyczne - te nie znajdują się w polu zainteresowania autorki kompendium. Niemniej jednak trudno oprzeć się wrażeniu, że tak marginalne potraktowanie medium Internetu jest niezrozumiałym ignorowaniem jego niekwestionowanego przecież wpływu na kształt gospodarki kulturalnej i przemianę samego odbiorcy, jego oczekiwań wobec kultury i gotowości uczestniczenia w niej oraz jej współfinansowania. Udział Internetu w kształtowaniu relacji ekonomicznych na rynku kultury jest przecież nie do podważenia.

Z drugiej jednak strony zmarginalizowanie znaczenia Internetu w organizacji i prowadzeniu instytucji kultury jest w pewnym sensie symptomatyczne dla myślenia o samym statusie wszelkich działań internetowych w funkcjonowaniu tego typu placówek. Instytucje kultury, choć zaanektowały na swój użytek internetowe formy promocji, doceniając przede wszystkim ekonomiczny wymiar tych działań i bezpośredniość kontaktu z odbiorcą, zachowują pewien dystans wobec tego medium. Być może wynika to ze strachu przed mechanizmami marketingowymi, w których instytucje kultury częstokroć dostrzegają siłę degradującą sztukę do poziomu produktu, a widza przemieniającą jedynie w klienta? Niewykluczone, że przyczyną owego dystansu jest nieumiejętność korzystania z możliwości, jakie zapewnia cyberprzestrzeń.

To, że instytucje kultury nadal traktują marketing internetowy z dużym dystansem, zdają się potwierdzać kolejne analizy strategii promocyjnych tychże instytucji oraz monitoring skuteczności wdrążonych już form marketingu online. Aby bliżej przedstawić ten problem, można przywołać tu dwa opracowania - powstały w roku 2009 raport dotyczący wykorzystaniu social media w promocji w promocji teatrów LORT (League of Resident Theatres) oraz wydaną w roku 2005 rozprawę Andrei Hausmann, poświęconą proble- 
mowi rozwoju strategii marketingowych w teatrach niemieckich. Pierwsza ze wspomnianych pozycji jasno dowodzi, że prawie wszystkie spośród badanych siedemdziesięciu trzech teatrów należących do LORT wykorzystują Internet do promocji, ale ich działania koncentrują się na tworzeniu różnego rodzaju treści bez możliwości ingerowania w nie przez użytkowników. Także platformy multimedialne czy portale społecznościowe są de facto miejscem do kopiowania zawartości stron internetowych z ewentualnym rozszerzeniem wybranych materiałów w ramach danej platformy. Devon Smith nie wspomina nigdzie, aby social media używane były do interaktywnych projektów mających choćby rys działań stricte artystycznych. Wyniki przeprowadzonych ankiet, których autor analizował największe portale społecznościowe i platformy multimedialne (Twitter, Facebook, MySpace, Flickr, YouTube) oraz blogi, wskazują, że projekty takie jak EFFIE BRIEST 2.0 są działaniami incydentalnymi. W tym też kontekście ciekawa może być druga z wymienionych pozycji, Theater-Marketing. Grundlagen, Methoden und Praxisbeispiele, koncentrująca się na przedstawieniu specyfiki działań marketingowych jednego z największych, jeśli nie największego z teatrów europejskich, jakim jest teatr niemiecki. Hausmann w swoim opracowaniu analizowała około stu pięćdziesięciu scen państwowych. Wprawdzie w wynikach swoich badań wspomina o znaczeniu Internetu w budowaniu wizerunku i promocji teatrów niejako na marginesie, niemniej jej spostrzeżenia są ważnym punktem odniesienia, gdy mówimy o ewolucji narzędzi internetowych. Okazuje się bowiem, że prawie wszystkie obserwowane przez Hausmann teatry komunikują się ze swoimi widzami za pomocą Internetu, ale szczytem ich możliwości jest wysyłanie do widzów maili bądź sprzedaż biletów online. Wśród wymienionych w książce koncepcji marketingowych, realizowanych dzięki narzędziom internetowym, uruchamiających przestrzeń bardziej bezpośredniej komunikacji z widzem, Hausmann wymienia zatem popularne wtedy elektroniczne księgi gości. Badaczka wspomina wprawdzie o tak zwanych „Online-Events”, ale jak można się domyślać, są to jedynie różnego rodzaju konkursy prowadzone na stronach internetowych bądź transmisje spektakli online. Wnioski, jakie płyną z analiz niemieckiej autorki, nie są raczej zaskakujące. Książka powstała jeszcze przed „erą Facebooka" i w większości odwołuje się do analiz prowadzonych w sezonie 2002/2003. Przywołuję jednak opracowanie niemieckiej badaczki z dwóch powodów. Po pierwsze dlatego, że analizy te są żywym dowodem znaczącej ewolucji narzędzi Internetu i zmiany sposobu myślenia o ich wykorzystaniu. Po drugie zaś dlatego, że omówione w książce sposoby budowania 
wizerunku za pomocą promocji online do złudzenia przypominają strategie stosowane obecnie w teatrach w Polsce. Jest to przykra konstatacja, ale jeśli spojrzeć na strategie promocji w Internecie większości polskich teatrów, ich podejście do możliwości social media także nie wykracza poza działania marketingowe. Entuzjazm organizatorów, widzów i krytyki, jaki towarzyszy na przykład transmisjom spektakli online, pozwala na formułowanie wniosku, że wydana przed siedmioma laty książka Hausmann mogłaby być u nas poczytną lekturą.

Projekty intermedialne, interaktywne, w których warunkiem uczestnictwa nie jest kupienie biletu i fizyczna obecność na widowni, lecz zalogowanie się na stronie projektu i dysponowanie w określonym czasie dostępem do Internetu, są czymś więcej niż jedynie próbą udanej promocji online. Aktualne pozostaje pytanie, czy internauci okazjonalnie biorący udział w tych projektach są również jedynie okazjonalnymi widzami-uczestnikami, zainteresowanymi technicznymi możliwościami takich eksperymentów, czy też może są widzami, dla których ten rodzaj obcowania ze sztuką jest po prostu kolejnym doświadczeniem, niekoniecznie wpływającym na podejmowane przez nich późniejsze wybory repertuarowe. Z pewnością każdy z uczestników tego rodzaju przedsięwzięć, jak również każdy internauta klikający na profil teatru, to potencjalny widz i klient, którego teatr w dobie kryzysu nie usunie pochopnie z listy znajomych. Można podejrzewać, że przedsięwzięcia takie jak łódzka I Ifigenia przestaną wkrótce budzić emocje widzów, jeśli rzeczywiście twórcy teatru nie odważą się przełamać pewnych utartych schematów wykorzystywania możliwości Internetu. Równie oczywiste wydaje się i to, że polskie sceny, które w ostatnim czasie z narastającą rozpaczą zabiegają o widzów, zaniechają sprzedawania swoich spektakli na Grouponie. Projekty takie jak EFFI BRIEST 2.0 czy różnego rodzaju gry "miejsko-teatralne" staną się prawdopodobnie stałym punktem programu także polskich teatrów, powoli odkrywających (nie)dyskretne uroki Internetu dla szerokiego spektrum swoich działań. Zresztą spektakl Ojciec Bóg w reżyserii Waldemara Śmigasiewicza, którego bohater - tytułowy Bóg - jeszcze przed premierą relacjonował na Facebooku swoje przeżycia, a po każdym spektaklu rozmawia, również za pośrednictwem Facebooka, z internautami o problemach wychowawczych, jakich przysparza mu niepokorny syn Jeszua, rozpoczął się już czerwcu 2010 roku.

Przestawione tu zdarzenia teatralne są efektem rewolucji internetowej, której znaczenie porównywane jest niekiedy do znaczenia rewolucji przemysłowej i która stała się - przy naszym czynnym w niej udziale - bezdy- 
skusyjnym faktem. Skala rozwoju Internetu w ostatnich kilku latach, w tym różnego rodzaju platform społecznościowych, kopiujących do świata wirtualnego relacje ze świata rzeczywistego, bez wątpienia jest zjawiskiem bezprecedensowym, choć od razu trzeba zastrzec, że tyleż fascynującym, ile niepokojącym. Działania będące częścią (i wytworem) wirtualnej rzeczywistości oraz konsekwencje tych działań są wieloaspektowe. Jednak biorąc pod uwagę specyfikę zjawiska (zwłaszcza prędkość transformacji medium, jakim jest Internet i ewolucja sposobów jego użycia), należy mieć świadomość, że są one również trudne do przewidzenia. Jedno pozostaje pewne nie można zatrzymać rozwoju Internetu, można jednak nauczyć się wykorzystywać jego możliwości także w przestrzeni działań teatru.

\section{Virtual stage - virtual audience. Social media In theatre promotion}

Summary: Using The new media In The theatre gives a wide range of possibilities for direct communication on a large scale, which offers space of exceptional nature for both The collective and The individual spectator. By using digital tools The theatre reopens itself for The audience - including those who so far remained beyond its reach, i.e. for economic or social reasons. The attempt to encourage spectator to interactively participate In specific projections and even participate In a game It becomes an element of marketing. Interestingly more and more often interactive marketing becomes an incentive for purely artistic activities. As an example one can name theatrical ventures "facebook live performance". Such projects become part of theatre repertoire and an element of promotion.

Key words: Theater, intermediality, interactive marketing

\section{Bibliografia:}

\section{Książki}

Erika Fischer-Lichte. 2008. Estetyka performatywności. Kraków: Księgarnia Akademicka.

Andrea Hausmann. 2005. Theater-Marketing. Grundlagen, Methoden und Praxisbeispiele. Stuttgart: Lucius \& Lucius. 
Hans-Thies Lehamnn. 2004. Teatr postdramatyczny. Kraków: Księgarnia Akademicka.

Ulf Otto. 2013. Internet Auftritte. Eine Theatergeschichte der neuen Medien. Bielefeld: Transcript.

Patrice Pavis. 2011. Współczesna inscenizacja. Źródła, tendencje, perspektywy. Warszawa: Wydawnictwo Naukowe PWN.

Arkadiusz Podlaski. 2011. Marketing społecznościowy. Tajniki skutecznej promocji w social media. Gliwice: Wydawnictwo Helion.

Sławomi Świontek. 2003. Tworzywa sztuki teatru. W: L. Karczewski, I. Lewkowicz, M. Wójcik (red.) 2003. Sławomira Świontka dwanaście wykładów z wprowadzenia do wiedzy o teatrze. Łódź: Wydawnictwo Uniwersytetu Łódzkiego.

\section{Źródła internetowe}

Ruth Towse. 2011. Ekonomia kultury. Kompendium. Warszawa: Narodowe Centrum Kultury.

"HAMNET" ==== Shakespeare's play adapted for irc http://www.hambule.co.uk/ hamnet/hscript.htm [20.03.2013]

Jacek Cieślak.2012. Teatr lubi sieć. http://www.rp.pl/artykul/949115.html?print=ta$k \& p=0[20.03 .2013]$

http://www.facebook.com/groups/MGTOB/?ref=ts\&fref=ts.20.03.2013 